\title{
Political Space - Local Political Structures in Northern Syria: The Case of the Country of Ida-Maras in the Eighteenth Century BC
}

\section{Introduction}

A large number of letters and administrative texts found in Mari, Šehnā-Šubat-Enlil, Ašnakkum (Chagar Bazar?), and elsewhere shed light on the history of the Upper Khabur, an area called Ida-Maras at the beginning of the I8th century BC.

This area was divided into small political units or "statelets", sometimes independent and sometimes subject to a stronger state or a remote foreign power (Ešnunna, Mari, Ekallātum, Elam ...). One of the characteristics of the so-called Mari period, from the time of Yahdun-Lîm to the time of Zimrī-Lîm, is the preeminent role played by the Haneans ("bedouins").

I will present the situation in the Upper Khabur during the reign of Zimrī-Lîm, who conquered the Ida-Maras region. I want to concentrate on textual evidence relating to the western part of this area, which is the area between the Wadi Jaghjagh and the source of the Khabur. ${ }^{\mathrm{I}}$ Texts from Mari offer a vivid and complex view of the history of the area and the people who lived there. The documentation, however, is far from complete, and we must remember that only some aspects of society and the economy are represented.

The period discussed covers only thirteen years and some months, from the accession of Zimri-Lîm until the defeat of Mari by Babylon (ca. I774-I76r BC). ${ }^{2}$ The most important part of our corpus of documents concerning Ida-Maras was not written by administrators or agents of the kingdom of Mari. Some administrators or generals who went to Ida-Maras, like Asqudum, Bașșum, Abum-El, Yassi-Dagan, went on various missions and sent reports back to the king of Mari. Although of course interesting, their reporting is of limited scope. For example, Abum-El stayed in the land of Ašnakkum only a few months between the tenth and eleventh regnal year of Zimrī-Lîm, in order to organise peace there. ${ }^{3}$ The administrative accounts from the Mari palace offer additional evidence, primarily precise indications of time, such as the length of reign of many local rulers. They also offer itineraries, because scribes went with the king's caravan and recorded presents which the king received from vassals or allies, or recorded presents he offered to them.

\footnotetext{
* Université Paris-I/UMR 7I92. The paper is translated by Michael Langlois.

I The following ideas are based on my unplublished Habilitation's Mémoire Nahur et l'Ida-Maraș, La correspondance d'Itûr-Asdû gouverneur de Nahur sous le règne de Zimrî-Lîm et autres documents.

2 See Charpin - Ziegler 2003, 169-246.

3 See Charpin I993, I65-I9I; Guichard 2009, 75-I20.
} 
Three other groups of texts, however, provide the most important source material. The first group represents letters coming from the authorities of the towns of Ida-Maras. Senders are mostly the local kings, but sugāgum officials are also represented, 4 and more rarely, the "elders". One letter was sent by the elders of Urgiš, 5 one by the elders of Gaššum, ${ }^{6}$ while another was sent by the elders of Kahat, but was originally not for the King of Mari.7 This document was probably intercepted.

The second group consists of letters from members of the Hanean groups, subjects, allies, and the army of Zimrī-Lîm. The transhumant sections of the Haneans provided the king potential access to information from a wide area. The Chief-of-Pasture defined it in this way: it stretches from Mount Ebih to the land of Yaptur (western part of the Khabur Triangle). ${ }^{8}$ This pasture zone corresponded roughly to the zone which the King of Mari tried to keep under his control. The man in charge of pasture and the transhumant group was called mer'ûm. In the North, we know of several chiefs of pasture for the time of ZimrīLîm, the first being perhaps Zakura-abum,9 the second Ašmad. ${ }^{\text {Io }}$ Letters from the last known mer'ûm's - Ibal-El and Ibal-pi-El - are more numerous. Hali-hadun may also have been a mer'ûm, or was at least closely associated with the same business during war between Hana Tribes.

Ibal-El explained this seasonal role of collecting information with a nice image:II

My Lord knows that I command Bedouins, and that like any merchant going through war and peace, Bedouins go through war and peace at (the time of) šepâtu-grain. ${ }^{\mathrm{I2}}$ As they travel they learn what the country speaks about.

So, the leaders of the Bedouins, who moved from place to place, sent letters from different countries, had lots of contacts, and met many informants. The implication is that they either had some knowledge of writing or that they employed scribes. This fact goes against the common idea that writing was used in urban contexts only or expresses only the viewpoint of the sedentary people. The tone, style and ideas of the mer'ûm make this correspondence original. In the Mari hierarchy, the rank of the mer'ûm was very high. The mer'ûm is a Bedouin and often expresses the desires and values of the Bedouins, and he had freedom of speech. So, it is not surprising to find in his letters the most exalted expressions as well as

4 See for example ARM XXVIII I20 from Luhayum, a town located in the land of Yaptur. For further comments on this letter see Guichard 2009, 75-I20.

5 FM II I25.

6 A.2126. This unpublished letter is quoted by Charpin - Ziegler 2003, 52 n. 203.

7 An unpublished text composed of several fragments that I identified in September 2009 in the Museum of Deir-Ez-Zor.

8 See FM VI 9 and Durand 2004, III-I97.

9 See Guichard 2002, II9-I68.

IO See Durand - M. Guichard I997, 33 n. 80.

II LAPO I6 333 and Charpin - Durand I990, I20-I22.

I2 For this interpretation, see Guichard 2002, $\mathrm{I} 6 \mathrm{I}-\mathrm{I} 6_{3}$. 
occasionally the worst criticism addressed to the king, but of course he acts as defender of the kingdom of Mari.

Finally, the third group of documents were sent by officials who settled in the midst of Ida-Maraș, such as Yamșûm, who was responsible for a Mari garrison in Ilān-șūrā.ı3 The most important correspondence of this category is without doubt that of Itūr-asdu. This very high official became governor of Nahur in the sixth year of Zimrī-Lîm and stayed in this town until the end of Mari. ${ }^{14}$ At least one hundred letters were sent by him from Nahur or its vicinity to Zimrī-Lîm. ${ }^{15}$ Because his correspondence is relatively abundant, detailed and regular, it represents our main source about the western part of Ida-Maras in the second part of the reign of Zimrī-Lîm, while we have many gaps in the preceding period. The activities of the governor were twofold. On the one hand, he was a representative of the king and a very precious informant. On the other hand he controlled a town and its countryside/ hinterland. The latter aspect of his power or responsibilities is less known (except at the beginning of his stay) because he usually avoided describing it. Far away from Mari, he seems to have had a relative degree of autonomy, making him similar to a small king. But unlike the rulers of Ida-Maras who lived in his vicinity, he could be dismissed from his post at any time. This fact considerably influenced the nature of his correspondence. The letters of the vassals can be suspected of hypocrisy, of lies or intentional distortion, because the vassals were, for any number of reasons, potential rebels. On the other hand, the letters of Itūr-asdu seem to be more reliable. He certainly had local interests that may have influenced his reports, but he never forgot his main function as an agent and representative of the Mari kingdom. He was not a native ruler and as such had no legitimacy. He himself checked the value of the information he managed to collect, and he often gives the origin of his sources.

It is interesting to note that we have several cases in which one event is related by two or three independent witnesses. We can compare their reports and observe that although the facts more or less coincide, the distribution of roles varies. Two army officers who take part in the same battle will never tell the same story but will turn the facts to their advantage. ${ }^{6}$ In his letters, Itūr-asdu wanted to give an ideal image of himself as a governor, and the Chief of Pasture wants the reports of his own actions to reflect the model of the ideal Chief of Pasture.

But the most important fact is that the events recorded on the Mari tablets were selected according to the interests of the king of Mari or of the leaders of the Hanean Bensimalite confederation.

I3 Charpin I989, 3I-III.

I4 See Guichard 2008, 43-53.

I5 The precise location of this town is unknown. J.-M. Durand has suggested that Kizil Tepe could be a good candidate. See Durand 2004, Nicolle 2004, I22. Nevertheless a better localization seems to be Derbassiye according to Charpin 2009, 69 .

i6 See the case of the battle of Pardu: FM II, p. 260-263. 
The correspondence usually adopts the viewpoint of Mari's political interests. Consequently the internal economy of the little states of Ida-Maras is not very well documented, and the real opinion of the local population is not so easy to grasp. A Mari official such as Itūr-asdu was obviously aware of this problem when he mentions in one of his reports the fact that there is a contradiction between what the people (muškēnum) say and what they really think or do: "people are small minded". ${ }^{17}$

The correspondence of Mari offers a view of the structures of Ida-Maras from the viewpoint of the Bensimalites. The function of the king's informant (official, vassal or nomad) is secondary. What matters is his political stance.

Instability was a characteristic of Ida-Maras, and events occasioned intense written communication between Mari and Ida-Maras. We therefore have access to a lot of incidental information that permits a partial reconstruction of the ancient society.

\section{Historical overview}

Because the land of Ida-Maras was divided into small political unities, its political history is difficult to depict synthetically. The easiest way may be to observe this history from the viewpoint of Mari. So our "roter Faden" being the Mari hegemony, the period of Zimrì-Lîm can be summarised like this:

After Samsī-Addu died, Išme-Dagan in Ekallātum and Yasmahy-Addu in Mari had lost control over the cities of Ida-Maras. Princes in exile came back to recover the throne of their ancestors, except when someone from the local elite had already taken their place. This certainly was the case in Nahur and Ašnakkum. Most cities were favourable to the Haneans, who fought for Zimrī-Lîm. However the new kings of Nahur and Ašnakkum became, during a very short period, leaders of the western Ida-Maras. They wanted to be treated like equal allies by Zimrī-Lîm. ${ }^{18}$ After the defeat of Yasmah-Addu in Mari, pressed by the Haneans, the new king came up to the Upper Khabur to conquer the land. The fall of the town of Kahat was the climax of his military campaign. The so-called "Zimri-Lîm Epic" commemorates his victorious war in the name of Enlil/Dagan. ${ }^{19}$ He was actually helped in the western part of the Khabur Triangle by the king of Burundum, Adalšenni. With the disappearance of the first kings of Nahur and Ašnakkum, local independence was lost.

From this moment until the middle of Zimrī-Lîm's reign, the history of Ida-Maras is rather confused and our information incomplete. Crises occurred in Nahur, and the town was destroyed. In Ašnakkum, Sammêtar became king. He faced serious difficulties, but he managed to keep his authority. Šūb-rām was at that time king of Qirdahat. The wars of

I7 A.482 (unpublished).

I8 See for example FM VI 6.

I9 Guichard (forthcoming). 
Zimrī-Lîm against the Benjaminites and Ešnunna provoked substantial troubles in IdaMaras, and many small kings disappeared. They were replaced by others. In Zalluhan for example there was an interesting political change. Zakura-abum, who was probably Chief of Pasture at the beginning of Zimrī-Lîm's reign, had driven away the local dynasty and officially became king of Zalluhan.

There was also a change in Zimrī-Lîm's strategy. In order to have better control over Ida-Maraș, Zimrī-Lîm annexed Nahur and settled a Mari garrison there. The town was repopulated, and Itūr-asdu was installed as governor in the sixth year of his lord. The Elamite war (Zimrī-Lîm year 9) was a disaster in the North. Many Mari vassals were killed because the war had provoked several palace revolutions, and Zimrī-Lîm's credibility was damaged. After the end of this conflict, Ašnakkum and its countryside descended into a kind of civil war. The most serious danger came from Ibâl-Addu of Ašlakkā, who prepared a major revolt against Mari. The war broke out during the winter of the twelfth year of Zimrī-Lîm. Ašlakkā was conquered, but Ibāl-Addu escaped. He continued his war in the northern part of Yapțur during the last year of Zimrī-Lîm²o, when there was a major struggle between Mari and Eluhut. The Mari documentation stops at the end of Zimrī-Lîm's thirteenth regnal year.

\section{General setting: the mountains, and the dry and humid Ida-Maras}

The general setting is that of the Khabur Basin. This region is defined by surrounding reliefs - the Tur 'Abdin chain to the North, the Djebel Abd el-Aziz, and the Sindjar -, and a bottleneck-shaped hydrographical web. The southern slope of the Tur 'Abdin represents a piedmont with a winter climate wet enough to allow dry farming.

This territory was integrated into the quite vague geographical and cultural (even political) concept of Subartum. It is both the dry farming area and the northern part of Mesopotamia. Inhabitants of the Upper Khabur may be called Šubareans. However, we can observe that Subartum/Subarean had negative connotations for the people of Mari. These terms implied the notion of foreign land or foreigners or even enemies. Inhabitants of the Khabur Triangle almost never call themselves Subareans. ${ }^{21}$

The northern part of Ida-Maraș may be called "lèt šadîm" that is "mountain border". We know that cities such as Ašlakkā and Nahur were close to the mountain slopes. A king of Talhayûm received the title sikkat šadîm litt. "mountain peg”. This expression is also used of a stronghold, and we can understand that this king played the role of a "lock" (= peg to close door etc.). His city was in a strategic location at the entrance of the corridor between Qaraça Dağ and Izala, a possible way to travel from the plain to the city of Burundum. The king of Talhayûm had (relative) control over mountain peoples whose raids were feared.

20 See Guichard 2009, 75-120.

2I See Guichard 2002, I34-I37. 
The wooded slopes of the mountains (simply called šadûm) were exploited by small kingdoms, notably Ašlakkā. ${ }^{22}$ The mountains were not totally uninhabited, since we sometimes read about the pabanh $\bar{u}$ (mountaineers) and some cities north of Talhayûm are explicitly designated as being located in the mountains. It seems that Eluhut, which was not a city of the piedmont, had authority over a major part of the Tur'Abdin. The mountains were a place of refuge for the people of the plain in case of insecurity.

As for the plain itself, archaeological surveys suggest that the area southwest of the Jaghjagh was not densely inhabited. ${ }^{23}$ The epigrapher may be surprised by this result, since texts mention the existence of numerous towns and villages shared by several countries, though very small, and most toponyms cannot be located. The modern Turkish border following the Tur'Abdin slopes prevents us from knowing precisely the archaeological situation to the north of the Khabur Triangle. The southern part was probably drier than the northern half. We would thus have to suppose a concentration of sedentary installations to the north of a line going through Chagar Bazar (Ašnakkum?), while the river banks of the Khabur would be inhabited by temporary nomadic installations only.

But texts show that a kingdom with two historical capital cities ( $\check{\text { S } / S u s a ̄, ~ Q i r d a h a t) ~}$ stretched to the south of Ašnakkum. Moreover, it has now been demonstrated by an itinerary dated to the time of Yasmah-Addu that Qirdahat, Tarnip and Zalluhan were located along the Khabur. ${ }^{24}$

Nonetheless, in the time of Zimrī-Lîm, Qirdahat and Tarnip declined. Tarnip is seldom mentioned and does not play any political role. Yet, it was a city that a king of Ešnunna boasted to have conquered in the Igth century. Qirdahat was conquered by Zimrī-Lîm during the conquest of Ida-Maras and part of its population was deported. It then lost its capital rank. It is seldom mentioned afterwards, but Zimrì-Lîm stopped there on his famous (military) expedition to Ugarit in order to muster his vassals.

As for Zalluhan, it was a town of secondary rank. It was occupied for a few years by an old Bensimalite ruler (Zakura-abum). The Bedouin presence was stronger in the southern part of Ida-Maras. Benjaminites settled in the surroundings of Nagar (Tell Brak) (the land of Qā and Isqā). They were, however, in the minority in this region. At the end of Zimrī-Lîm's reign, Bensimalites drove the king of Ašnakkum out of Tarnip, a clear sign of pressure from the bedouins. ${ }^{25}$

Hurrian-speaking population elements were rather concentrated to the north, from Hazzikkanum to Ašlakkā. But the mix of population leads us to speak of a Hurro-Amorite society. The local language used by Haneans or sedentaries of nomadic descent was Amorite. Obviously Hurrian onomastics in the northern cities suggests an important place for

22 See FM VIII 3.

23 See Lyonnet 2000, 24I-253.

24 See Charpin 2009, 59-74.

25 ARM XXVIII I04. 
the Hurrian language. To be a representative (hazannum) ${ }^{26}$ of Ašlakkā, one had to speak “Subarean", i.e. Hurrian. The dominant cultural and political setting was, however, Semitic and the cultural language was of course Akkadian. One remembers that Yasmah-Addu did not speak Amorite. ${ }^{27}$

\section{Symbiosis between Hana shepherds and Ida-Maras farmers}

There is a relative symbiosis between Bensimalite and sedentary shepherds. Bedouins came with their flocks to the towns to get grain after the harvest. In one case a group leaves the Qattunân province to go to Admatum in the Aslakkā region. ${ }^{28}$ We also see one of their groups go through Wadi Jaghjagh to milk and make cheese. ${ }^{29}$ The gift of grain from farmers was accompanied by real ceremonies. The two different groups would meet in a given location. Bedouins would begin by offering their presents to city rulers. The Chief of Pasture would then give a speech praising the relationship between shepherds and farmers. Finally, farmers would present the Bedouins with bags filled with grain, hence called še'um šepâtum. $3^{\circ}$

On a regular basis Hana Bedouins and townspeople would organise covenantal ceremonies, which included a sacrifice of a donkey foal. In case of conflicts it was customary to recall the existence of these pacts called "donkey foal". The flocks were then permitted to graze on land belonging to the settled population, and also given access to water. Hana families were allowed to reside in the midst of the settled population, but they risked being blackmailed in case of conflict between Bedouins and city rulers, which happened with the king of Ašnakkum, Išme-Addu.

Such alliances offered mutual protection in the event of an external attack. In the specific setting of Zimrī-Lîm's time, Bedouins seem to have had a clear military advantage over their sedentary brothers. Very high tensions may have risen from this imbalance. Thus the Yaptur was often at odds with the Hana people, and it is in this land that a Bensimalite clan was massacred. $3^{\mathrm{I}}$

26 For this function, see Marti 2010, I54-I62.

27 See Charpin - Ziegler 2007, 55-77.

28 ARM XXVII 20.

29 Unpuplished letter (M.6488).

30 More examples in: Guichard (forthcoming) b.

3I See Durand I988, 97-II3. 


\section{The political and spatial organization of Ida-Maras}

In the western part of the Khabur, the most prominent cities from a political standpoint were Nahur, Ašnakkum, Susā (or Šusā), Talhayûm, and Ašlakkā. Urgišs, though without a king, except for a very short time, is also mentioned very often. Šinah and Hurrā are often associated with it. There was also a king in Šuduhum, Tarmanni, Anamaš, Zalluhan, and so on. Even though there are a few attestations of Putrum (= Putrāa), this city became important only after the reign of Zimrì-Lîm, since Samsu-iluna mentioned it among his conquests in one of his year names..$^{32}$ It was anyway located west of the Khabur Triangle.

By the time of Zimrī-Lîm, Talhayûm was not counted as part of the Ida-Maraș although the city is west of the Khabur Triangle. All other cities that are mentioned belong explicitly to the Ida-Maras. Some have seen in Ida-Maras either the name of a tribe that would have given its name to the Khabur Triangle,33 or a descriptive name of the region meaning "Difficult side". 34

The Ida-Maras is a flexible city confederation. Elders and kings belonging to this political entity would meet on a regular basis, mainly to discuss military matters, it seems. They could thus help one of their members in case of a succession problem. There is no fixed location for these gatherings. Some kings of the Ida-Maras had greater power than others. This was due to the importance and prestige of their city, but also to their own personality. The king of Ilān-șūrā (Haya-Sūmu), a city located east of the Jaghjagh, was their leader. Sammêtar of Ašnakkum and Šūb-rām of Susā were among the great representatives of the Ida-Maras. They were thus essential interlocutors for the king of Mari.

The Ida-Maras was divided into several "regions". Each of these regions was dominated by an urban center that hosted a royal family. Thus Ašnakkum represented the capital city of a country named Sūmum. Urgiš, Šinah, Hurrā and Šuduhum were its satellites. But these cities remained largely autonomous. The towns of the Sümum had stronger links between themselves than with all other cities of the Ida-Maras. Such a relationship must have been of a tribal nature. The Yaptur, which was originally part of the Ida-Maras had a structure very similar to that of the land of Sūmum. Its capital city was Talhayûm. The case of Susā is more complex. There are indications that Susa was south of Ašnakkum. But its king Šūb-rām also had authority over the Yaptur. This was according to Mari's will, but contested in the Yaptur itself. There was an area to the north-east of the Ida-Maras which must have been under the leadership of Nahur. But the decline of Nahur and its transformation into a Mari garrison probably allowed an extension of Ašlakkā. The place of Zalluhan in this political space is not clear. Sammêtar of Ašnakkum and Šūb-rām of Susā probably tried to bring the city within their power spheres.

32 See Horsnell I999, 2 II.

33 For this question see Charpin 2003, 15-16.

34 "Le piedmont du Maraz", Durand I990, 7. 
It is possible that political zones were structured around wadis. We know that the Sârum (perhaps modern Wadi Zerkan) ${ }^{35}$ represented the boundary between Ida-Maras and Yaptur. Likewise, we could imagine that kingdoms could stretch along the wadis. At first sight what we know of Tarnip-Ašnakkum and Qirdahat-Susa contradicts this possibility. We rather observe a discontinuity in political space. Was the Sūmum fragmented?

A demographic study of the texts has yet to be done. Political capital cities are called ribêtum or alānu rabêtum. But since a city such as Ašnakkum could easily be deprived of its inhabitants, we may doubt that the population was very dense in the "capital cities". Nahur was almost totally abandoned at the beginning of Zimrī-Lîm's reign. A small group remained on its acropolis alone before a thousand people from Mari eventually settled there. The better-known cases of Zalluhan and Šuduhum show that the population was dispersed in villages. The city with its walls served first of all as a place of gathering and protection, as shown by the alerts described in several letters. Some of these ribêtum-cities with their palace and typical inhabitants could simply be great structures destined to host royal families.

The dispersion of the population in Ida-Maras is the main characteristic that caught the nomads' attention; they compared it to the dispersion of their sheep during transhumance.

\section{Local institutions}

The people of Ida-Maraș are regularly designated by the term muškēnum. The ümšarhum category, translated "servant", includes totally or partially that of the muškēnum. The ūmšarhum that we know are always attached to the service of a king or queen. They seem to be confused with the village people. They are potential victims of poor harvests and creditors, which occasion them to flee. Zakura-abum mentions an edict of andurārum decreed by the King of Mari. It was about the Ida-Maras. But the case he mentions shows that all problems have not been overcome and all umšarhum have not come back to Zalluhan. ${ }^{6}$ The umšarhum could also plot against their king, as was the case in Zalluhan. 37

There were merchants and craftsmen, but they are seldom mentioned, ${ }^{8}$ while seemingly important commerce took place between Eluhut and several cities on the plain, such as Urgišs, Šuduhum and Hurrā.

Rural or urban communities were led by a sugāgum and elders. Urgišs, probably one of the most populated districts of the western Ida-Maras, was ruled by a sovereign assembly. It was sometimes the sheikh who represented the city and sometimes the elders. At Urgiš, the

35 See Guichard 2006.

36 M.5413. See Durand I998, 564 .

37 A.2822+ (unpublished).

38 ARM XXVIII III may mention a kārum in Šusā in broken context. 
assembly could condemn a traitor to be stoned by the community. 39 We know that it took up numerous political initiatives during Zimrī-Lîm's reign.

These "communal" institutions coexisted more or less easily with the families that had taken power. Male members of these families were called mādarum. In the city of Ašlakkā, seat of the royal residence of Ibâl-Addu, a sugāgum also performed his duties, but was deprived of any external representative role. Generals were very often close relatives of the kings.

Although the kings ruled over seemingly small territories, they insisted on bearing the title of king, šarrum. This in itself did not seem to pose a problem to a mighty king such as Zimrī-Lîm. Of course he could assimilate them without telling it overtly to his šāpițum or šaknum. The legitimacy of the kings rested on a complex and unstable balance between hereditary right, popular support, and the suzerain's approval. The meaning of the frequent royal visits to Nagar, a city deprived of any political role, is shown by the documentation from Tall Leilan. $4^{\circ}$. A king of Šuduhum,,$^{41}$ the ephemeral king of Urgiš ${ }^{2}$ and a king of Tarmanni43 referred to their visit to this place without mentioning the temple of the Lady of Nagar. It seems that this goddess brought them the divine help they sought.

The power of the kings of Ida-Maras was limited. They could exercise their power in a consensual way only. We thus see Šūb-rām gather his subjects to ask for their opinion concerning his intent to go down to Mari. Unhappy with a plot against him in his kingdom, Zakura-abum offers to abdicate.44 In Talhayûm, the king Yawi-El was less successful. He was killed because of his subjects' betrayal. The city elders probably organized the coup. 45 This misadventure, which must have had numerous precedents, could explain why royal families stayed away from cities where communal power was too strong. Ašnakkum may fit in this category as we have seen. However, the disagreement between the king of Ašnakkum, Sammêtar, and the people of Urgiš had to lead to its reversal.

Royal families were like a pool of future kings. There was thus a rather strong competition among these mādarum. They assumed the right to declare war, although they had no throne. Thus, even a ruling king was always threatened by a rival in exile. Some successions were thus questioned, which gave rise to numerous conflicts of usually short duration. A family or a family branch could thus be deprived of its possessions overnight. The most typical case is that of Zakura-abum of Zalluhan. This Bedouin leader had become king by forcefully taking the seat of the local dynastic ruler. The sons of the latter were then exiled to neighboring kingdoms. $4^{6}$ They caused a lot of trouble to Zakura-abum during his short

39 See Guichard 2004.

40 See Eidem 2000, 255-264; Sasson 1997, 475-490.

4I M.9738: 3'.

42 ARM XXVIII 44bis. See Guichard I997, 329-339.

43 Unpublished letter (A.3II6).

44 A.2822+ (unpublished).

45 See Guichard (forthcoming) c.

46 ARM XXVIII 53. 
reign. He died suddenly, taken by a sickness. His son should have taken his place. He was quickly dealt with and replaced by Zakura-abum's rival.

These kings lived in fortified buildings, palaces where they kept their wives and meagre treasure. They had their own scribes whom they jealously kept. The affairs of the palace were handled by the šukallum, "vizier". There were notorious traitors among them. The scribe of Ibâl-Addu organized a plot against his master. ${ }^{47}$ Zakura-abum escaped the upheaval of his own šukallum. One way for a king to extend his control over a territory was to spread his harem throughout several cities. That is what the kings of Ilān-sūuāà ${ }^{8}$ and Ašlakkā did.49

One last fundamental point must be underlined. The textual documentation confirms the observation made by the archaeologists in the field. The city population was very unstable. A city could be deserted overnight and be occupied again a few years later. In letters this phenomenon is called häbirūtum, that is, "emigration". The most spectacular case is that of Ašnakkum. A war was ongoing. The king of Ašnakkum felt threatened and preferred to move out with his family and wealth to his neighbour in Susā. Other inhabitants of Ašnakkum also began to leave the city. The one who witnessed this saw Ašnakkum become a mere place of bivouac. $5^{\circ} \mathrm{A}$ city that was unhappy with its suzerain could threaten to emigrate. This phenomenon generated the existence of numerous hābiru. An unpublished document indicates that all the kings of Ida-maras had hābiru in their armies. Among the leaders of these hābiru was a man named Asqur-Addu. He was probably a mādarum whose purpose was to get back his lost city of Nahur. Another typical leader, Samsī-Erah, was a commoner who had given himself the right to declare war. He and his band of hābiru were responsible for the death of Yawi-El at Talhayûm and for looting the city of Susā and helping the people of Mari to fight against the Elamites; he was subsequently murdered in an ambush. His brother became the leader of the group and engaged in similar activities..$^{5 \mathrm{r}}$

\section{Conclusion}

In conclusion, the Upper Khabur region or Ida-Maras . of northern Mesopotamia can be characterized as politically fragmented during the early second millennium BC. Textual evidence offers an interesting perspective on this area, which at times was under the hegemony of the Mari kingdom. The overlords from Mari sometimes replaced local rulers with their own vassals, leading to constant conflicts with local people and local forms of government.

47 For this affair see ARM XXVIII 53.

48 This information comes from one of the unpublished letters of Itûr-asdu, Mari's governor.

49 See Ziegler I999, I-26.

50 A.2434: 32'. See Guichard 2009, II4-II5.

5I Guichard 20II, 29-93. 
The political history of the Ida-Maras is not easily written due to this political fragmentation, but it is clear that it was a flexible confederation of kings and elders. Some cities were governed by a sovereign assembly, while others were led by elders or sheikhs. The kings ruled over small territories, yet their power was overall fragile due to the turbulent political history of the area.

Texts also tell us about the ways in which nomads ("bedouins") interacted closely with the sedentary farmers through peaceful exchange of goods. Although they constituted two distinct political communities, their relationship can be described as a symbiosis due to the important exchange between livestock and agricultural products, which was important to both communities.

There is also evidence for the presence of Hurrian speaking people that were concentrated to the north of the area and most likely mixed closely with Amorites.

Last but not least, one should note the observation that the city population was generally unstable, indicating frequent migrations of city populations (ḩābirūtum), which often took place due to armed conflicts or economic crises in the area.

\section{Bibliography}

Charpin 1989

D. Charpin, Archives royales de Mari, XXVI/2, I989, 3I-III.

Charpin - Durand I990

D. Charpin - J.-M. Durand (eds.), Mohammed Diyab, une ville du pays d'Apum, Cahiers de N.A.B.U. I, I990, I20-I22.

Charpin 1993

D. Charpin, Išme-Addu d'Ašnakkum, MARI 7, I993, I65-I9I.

Charpin 2003

D. Charpin, La toponymie en miroir, RA 97, 2003, I5-16.

Charpin - Ziegler 2003

D. Charpin - N. Ziegler, Mari et le Proche-Orient à l'époque amorrite. Essai d'histoire politique, FM V, 2003.

Charpin - Ziegler 2007

D. Charpin - N. Ziegler, Amurritisch lernen, Mél. Hunger, WZKM 97 (Wien 2007) 55-77.

\section{Charpin 2009}

D. Charpin, Un itinéraire paléo-babylonien le long du Habur, “Šuduhum, un royaume d'IdaMaraș, et ses rois Yatâr-malik, Hammī-kūn et Amud-pā-El”, in: E. Cancik-Kirschbaum N. Ziegler (eds.), Entre les fleuves I. Untersuchungen zur historischen Geographie Obermesopotamiens im 2. Jahrtausend, BBVO 20, 2009, 59-74. 


\section{Durand 1988}

J.-M. Durand, Les Anciens de Talhayûm, RA 82, I988, 97-II3.

\section{Durand 1990}

J.-M. Durand, Mille et une capitale à redécouvrir, Dossiers d'archéologie, n55, déc. 1990, 7 .

\section{Durand - Guichard 1997}

J.-M. Durand - M. Guichard, Les rituels de Mari, Florilegium Marianum III, I997, 33 n. 80.

\section{Durand 1998}

J.-M. Durand, Documents épistolaire du palais de Mari, tome II, Littératures Anciennes du Proche-Orient I7, I998.

\section{Durand 2004}

J.-M. Durand, Peuplement et sociétés à l'époque amorrite: (I) les clans bensimalites, in: C. Nicolle (ed.), Nomades et sédentaires dans le Proche-Orient ancien, CRRAI XLVIe (Paris 2000), Amurru 3, 2004, III-I97.

\section{Eidem 2000}

J. Eidem, Northern Jazira in the I8th Century BC. Aspects of Geo-Political Patterns, in: O. Rouault - M. Wäfler (eds.), La Djéziré et l'Euphrate syriens de la Protohistoire à la fin du IIe millénaire av. J. C., Subartu VII, 2000, 255-264.

\section{Guichard 1997}

M. Guichard, Zimrî-Lîm à Nagar, MARI 8, I997, 329-339.

\section{Guichard 2002}

M. Guichard, Le Šubartum occidental à l'avènement de Zimrî-Lîm, FM VI, 2002, II9-I68.

\section{Guichard 2004}

M. Guichard, La lapidation à Urgiš, NABU 2004/29.

\section{Guichard 2006}

M. Guichard, Sur l'identification du Sârum, affluent du Habur et son implication sur la géographie politique du Haut-Habur au temps de Zimrî-Lîm, NABU 2006/37.

\section{Guichard 2008}

M. Guichard, La route des marchands assyriens vue depuis Nahur, in: J. G. Dercksen (ed.), Anatolia and the Jazira during the Old Assyrian Period, OAAS 3, PIHANS III, Leiden 2008, $43-53$.

\section{Guichard 2009}

M. Guichard, Suduhum, un royaume d'Ida-Maras, et ses rois Yatâr-malik, Hammī-kūn et Amud-pā-El, in: E. Cancik-Kirschbaum - N. Ziegler (eds.), Entre les fleuves I. Untersuchungen zur historischen Geographie Obermesopotamiens im 2. Jahrtausend, BBVO 20, 2009, $75^{-120 .}$

\section{Guichard 20II}

M. Guichard, Un David raté ou une histoire de habiru à l'époque amorrite. Vie et mort de Samsī-Ērah, chef de guerre et homme du peuple, in: J.-M. Durand - T. Römer - M. Langlois (eds.), Le jeune héros. Recherche sur la formation et la diffusion d'un thème littéraire au Proche-Orient ancien, Actes du colloque du Collège de France du 6 et 7 avril 2009, OBO 250, 20II, 29-93. 


\section{Guichard (forthcoming)}

M. Guichard, L’Épopée de Zimri-Lim “taureau du combat”, FM forthcoming.

\section{Horsnell 1999}

M. Horsnell, The Year-Names of the First Dynasty of Babylon, vol. 2, I999, 2II.

\section{Lyonnet 2000}

B. Lyonnet, Méthode et résultats préliminaires d'une prospection archéologique dans la partie occidentale du Haut-Khabour, depuis le Néolithique jusqu'à la fin du IIe millénaire av. n. è., in: O. Rouault - M. Wäfler (eds.), La Djéziré et l'Euphrate syriens de la Protohistoire à la fin du IIe millénaire av. J. C., Subartu VII, 2000, 24I-253.

\section{Marti (2010)}

L. Marti, Les hazannu à Mari et sur le Moyen-Euphrate, in: L. Kogan et alii (eds.), City Administration in the Ancient Near East, CRRAI 53 (Moscou 2008), 2010, I53-I69.

\section{Nicolle 2004}

C. Nicolle (ed.), Nomades et sédentaires dans le Proche-Orient ancien, Amurru 3, 2004, I22-I37.

\section{Sasson 1997}

J. Sasson, The Vow of Mutiya, King of Shekhna, in: G. Young - M. Chavalas - R. Averbeck (eds.), Crossing Boundaries and Linking Horizons, Studies in Honor of M. Astour (Bethesda I997) $475-490$.

\section{Ziegler 1999}

N. Ziegler, Le harem du vaincu, RA 93, I999, I-26. 